\title{
Application of sulphur isotope ratios to examine weaning patterns and freshwater fish consumption in Roman Oxfordshire, UK
}

\author{
Olaf Nehlich $^{\mathrm{a}, *}$, Benjamin T. Fuller ${ }^{\mathrm{a}, \mathrm{b}}$, Mandy Jay ${ }^{\mathrm{a}, \mathrm{c}, \mathrm{d}}$, Alice Mora ${ }^{\mathrm{a}}$, \\ Rebecca A. Nicholson ${ }^{\mathrm{e}}$, Colin I. Smith ${ }^{\mathrm{a}, \mathrm{f}}$, Michael P. Richards ${ }^{\mathrm{a}, \mathrm{g}}$ \\ a Department of Human Evolution, Max Planck Institute for Evolutionary Anthropology, Deutscher Platz 6, D-04103 Leipzig, Germany \\ ${ }^{\mathrm{b}}$ Laboratory of Animal Biodiversity and Systematics, Centre for Archaeological Sciences, Katholieke Universiteit Leuven, \\ Blijde Inkomststraat 21, B-3000 Leuven, Belgium \\ ${ }^{c}$ Department of Archaeology, Durham University, South Road, Durham DH1 3LE, United Kingdom \\ ${ }^{\mathrm{d}}$ Department of Archaeology, University of Sheffield, Northgate House, West Street, Sheffield S1 4ET, United Kingdom \\ ${ }^{\mathrm{e}}$ Oxford Archaeology South, Janus House, Osney Mead, Oxford OX2 OES, United Kingdom \\ ${ }^{\mathrm{f}}$ Archaeology Program, La Trobe University, Melbourne, Vic. 3086, Australia \\ ${ }^{\mathrm{g}}$ Department of Anthropology, University of British Columbia, Vancouver, British Columbia, Canada V6T 1 Z1
}

Received 7 February 2011; accepted in revised form 7 June 2011; available online 15 June 2011

\begin{abstract}
This study investigates the application of sulphur isotope ratios $\left(\delta^{34} S\right)$ in combination with carbon $\left(\delta^{13} \mathrm{C}\right)$ and nitrogen $\left(\delta^{15} \mathrm{~N}\right)$ ratios to understand the influence of environmental sulphur on the isotopic composition of archaeological human and faunal remains from Roman era sites in Oxfordshire, UK. Humans $(n=83)$, terrestrial animals $(n=11)$, and freshwater fish $(n=5)$ were analysed for their isotope values from four locations in the Thames River Valley, and a broad range of $\delta^{34} \mathrm{~S}$ values were found. The $\delta^{34} \mathrm{~S}$ values from the terrestrial animals were highly variable $(-13.6 \%$ to $+0.5 \%$ o $)$, but the $\delta^{34} \mathrm{~S}$ values of the fish were clustered and ${ }^{34} \mathrm{~S}$-depleted $(-20.9 \%$ to $-17.3 \%$ o $)$. The results of the faunal remains suggest that riverine sulphur influenced the terrestrial sulphur isotopic signatures. Terrestrial animals were possibly raised on the floodplains of the River Thames, where highly ${ }^{34} \mathrm{~S}$-depleted sulphur influenced the soil. The humans show the largest range of $\delta^{34} \mathrm{~S}$ values $\left(-18.8 \%\right.$ to $+9.6 \%$ ) from any archaeological context to date. No differences in $\delta^{34} \mathrm{~S}$ values were found between the males $(-7.8 \pm 6.0 \%$ ) and females $(-5.3 \pm 6.8 \%$ ), but the females had a linear correlation $\left(R^{2}=0.71 ; p<0.0001\right)$ between their $\delta^{15} \mathrm{~N}$ and $\delta^{34} \mathrm{~S}$ compositions. These $\delta^{34} \mathrm{~S}$ results suggest a greater dietary variability for the inhabitants of Roman Oxfordshire than previously thought, with some individuals eating solely terrestrial protein resources and others showing a diet almost exclusively based on freshwater protein such as fish. Such large dietary variability was not visible by analysing only the carbon and nitrogen isotope ratios, and this research represents the largest and most detailed application of $\delta^{34} \mathrm{~S}$ analysis to examine dietary practices (including breastfeeding and weaning patterns) during the Romano-British Period.
\end{abstract}

(C) 2011 Elsevier Ltd. All rights reserved.

\section{INTRODUCTION}

\footnotetext{
* Corresponding author. Tel.: +49 3413550 355; fax: +49 341 3550399.

E-mail addresses: olaf@nehlich.com,nehlich@eva.mpg.de (O. Nehlich).
}

The stable isotope ratio analysis of sulphur in bone collagen has recently become more prevalent in archaeological research due to technological advances in mass spectrometry (Giesemann et al., 1994; Kester et al., 2001). 
Sulphur isotope ratios $\left({ }^{34} \mathrm{~S} /{ }^{32} \mathrm{~S}\right.$ or $\left.\delta^{34} \mathrm{~S}\right)$ of tissues reflect the biologically available local geological sulphur values, such that the tissue sulphur isotopic signatures vary by location (Hobson, 1999) and dietary behaviour (Richards et al., 2001). In combination with carbon $\left(\delta^{13} \mathrm{C}\right)$ and nitrogen $\left(\delta^{15} \mathrm{~N}\right)$ stable isotope ratios, the number of applications of $\delta^{34} \mathrm{~S}$ measurements in the field of archaeological science has been increasing; for example, sulphur isotope ratios have been used to distinguish between marine and terrestrial dietary resources (Craig et al., 2006; Linderholm et al., 2008b), assess the input of freshwater resources in diets (Privat et al., 2007; Hu et al., 2009; Nehlich et al., 2010), and used to track mobility and the migration patterns of ancient individuals (Vika, 2009). However, little research has been conducted on skeletal material from the UK and none from the Romano-British Period.

The focus of this present study was to use sulphur isotope ratios to examine the diet and weaning patterns of Roman era individuals from the sites of Tubney Wood Quarry and Queenford Farm, UK. Previous work on the Queenford Farm collection by Fuller et al. (2006a) found that a number of the skeletons from this site had bone collagen $\delta{ }^{13} \mathrm{C}$ values most consistent with $\mathrm{C}_{3}$ plant environments, but had elevated $\delta^{15} \mathrm{~N}$ values and that could have been the result of the consumption of freshwater protein such as fish. A primary goal of the $\delta^{34} \mathrm{~S}$ analysis of the Queenford Farm material was to provide additional evidence on the importance of freshwater protein (fish) as a dietary resource during the Roman Period in Britain. In addition, $\delta^{34} \mathrm{~S}$ measurements applied to archaeological infants and children have never been studied, and it is unknown (although not expected) if there is a measurable trophic level effect during breastfeeding and weaning (as is the case with $\delta^{13} \mathrm{C}$ and $\delta^{15} \mathrm{~N}$ values Fogel et al., 1989; Fuller et al., 2006b). All of the $\delta^{34} \mathrm{~S}$ results were analysed and compared in relation to $\delta^{13} \mathrm{C}$ and $\delta^{15} \mathrm{~N}$ values to create a more detailed understanding of the isotopic composition of the Thames River Valley and Romano-British dietary behaviour.

\section{BACKGROUND INFORMATION}

\subsection{Geography}

The skeletal material used for this study is from archaeological sites located in and south of the city of Oxford, Oxfordshire, UK along the River Thames and River Ock (see Fig. 1). The River Thames is the main river draining south central and southeastern England. The upper basin is fed from two main areas: the Cotswold Hills in Gloucestershire (where the River Thames has its spring) and the Southern Midlands, and it has a large estuarine mouth that empties into the North Sea on the east coast of England (Jarvie et al., 2002). Several tributaries join the River Thames as drainage from the Cotswold Hills (e.g., River Coln, River Windrush, River Evenlode, etc.) and make it the most important water system for this area since the Pleistocene (Bridgland and D'Olier, 1995). The main drainage rivers for the Southern Midlands are the River Cherwell and the River Thame which join together shortly after Oxford and create the main River
Thames. The River Ock joins the River Thames at Abingdon upstream of where the River Thame enters the Thames. Large areas along the River Thames are flood plains which consist mainly of gravels from the Cotswold Hills or the Midlands (Bridgland, 1994).

\subsection{Geology}

The geology of the bedrock is the major factor controlling the mobile (soluble) sulphur of the hydrosphere, and consequently the biologically bound sulphur found in plants and animals (Hitchon and Krouse, 1972; Krouse and Levinson, 1984; Krouse, 1989). There are three main sources of mobile sulphur in the Thames River Valley. The first is the local sulphur released via the weathering of the bedrock geology of the survey area. The second is the soluble sulphur transported by the River Thames and its tributaries from further upstream. The third is the sulphur of the precipitation. The input of ${ }^{34}$ S-enriched sea water sulphates $(+20.3 \%)$ in Oxfordshire is minor, as most of it is deposited within $\sim 20 \mathrm{~km}$ of the coastline (Coulson et al., 2005; McArdle et al., 1998).

The geology of Oxfordshire is partitioned into several bands of different geological formations (see Fig. 2) and was described by Arkell (1947). South of Oxford, bands of clay cross the landscape, and this assemblage is made up of kaolin-mica minerals (Jeans, 2006). The river beds of the Thames and Thame mainly flow through Oxford Clay and Kimmeridge Clay deposits. These clays date to the Jurassic and Cretaceous Eras and consist of sandstone, mudstone, siltstone, and limestone (details are given in Table 1). These geological layers are partially covered with alluvial stream sediments from the Midlands (Kinniburgh and Beckett, 1983).

The two main areas which are drained by the River Thames and its tributaries are the Cotswold Hills and the Southern Midlands. Geologically the Cotswold Hills are middle Jurassic (Bathonian) limestone of the Great and Lower Inferior Oolite group, whereas the Southern Midlands are mainly characterised by a Mesozoic Lias group (Watts et al., 2000). The Lower Inferior Oolite sediments of the Cotswold Hills were deposited during the Lias and Trias (Mudge, 1978), and are composed of a smectite-mica assemblage (Jeans, 2006). The uplift of the 'Severn Basin' during the Quaternary changed the drainage direction of most rivers of the Midlands (Watts et al., 2005), and also created the modern river-bed of the River Thames. Elevated areas of the Cotswold Hills are covered with alluvial material from the Midlands, which was deposited before this area was uplifted. The alluvial materials suggest that southern England was covered by seawater before the uplift (Gibbard et al., 1988), and this has major implications for the geochemical composition of the sediments. Thus, the raising of the Cotswold Hills generated a complex geological pattern with diverse geochemical features.

\subsection{Isotope geochemistry}

To understand the sulphur isotope ratios of the biosphere, it is necessary to consider the local geological and 


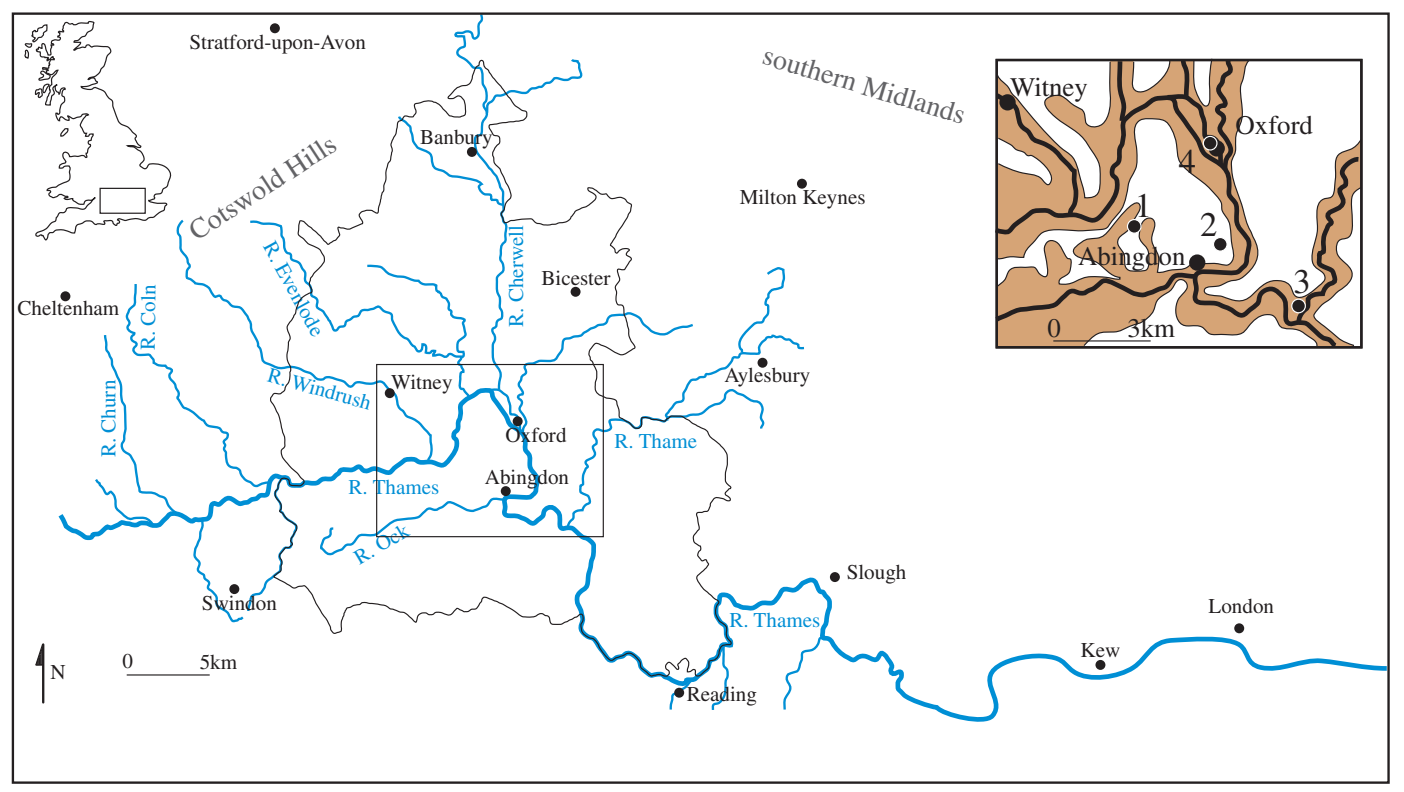

Fig. 1. River Thames with major tributaries in Oxfordshire (area is outlined). Inset shows the location of the archaeological sites and floodplains (grey area) along the River Thames (taken from BGS geoindex: www.bgs.ac.uk/geoindex/) and its tributaries $(1=$ Queenford Farm, Dorchester-on-Thames; 2 = Barrow Hills, Radley; 3 = Tubney Wood Quarry, Tubney; 4 = Queens' College, Oxford).

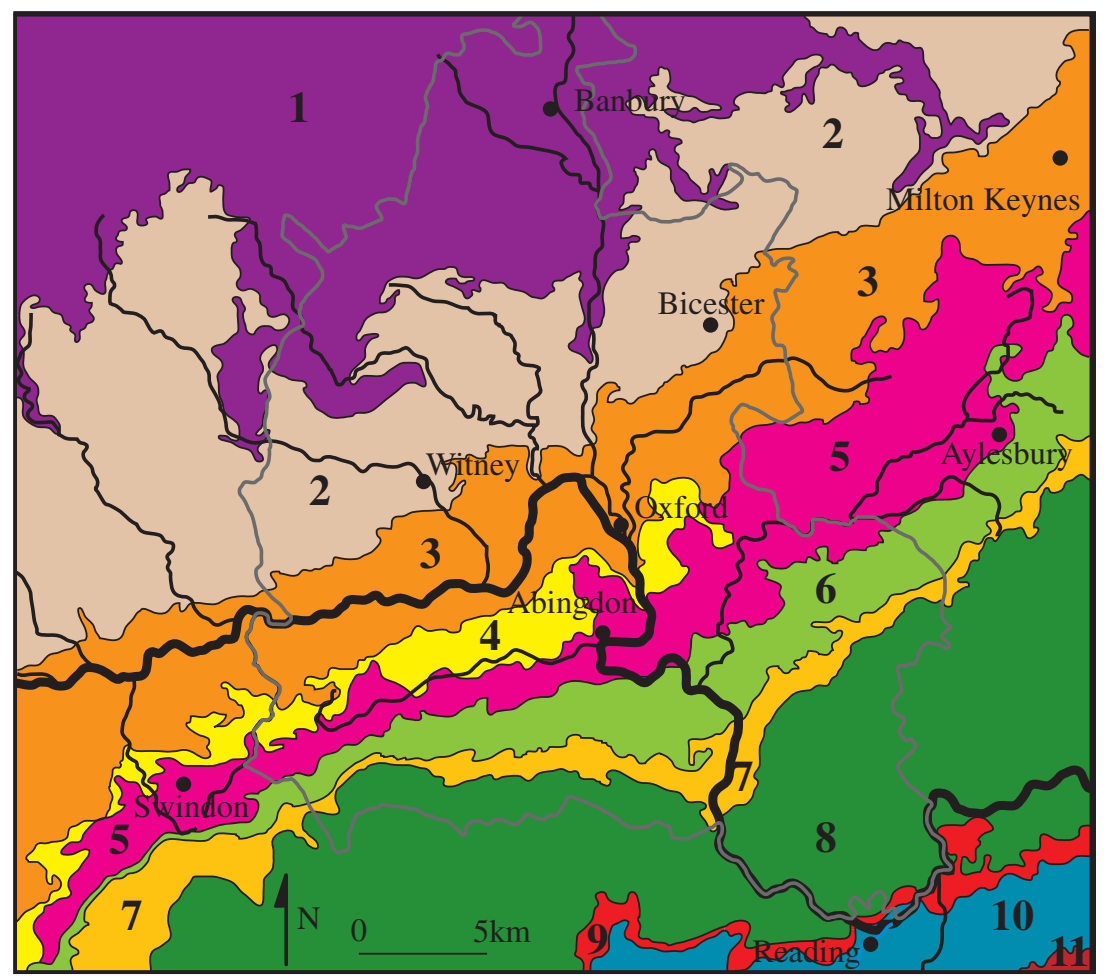

Fig. 2. Underlying geological formations of the River Thames and its tributaries in Oxfordshire (geological formation 1 - Lias group; 2 Great Oolite group; 3 - Kellaways formation and Oxford Clay formation; 4 - Corallian group; 5 - West Walton formation, Ampthill Clay formation and Kimmeridge Clay formation; 6 - Gault formation and upper greensand formation; 7 - Grey chalk subgroup; 8 - White chalk subgroup; 9 - Lambeth group; 10 - Thames group; 11 - Bracklesham group and Barton group; data taken from GeoIndex, British Geological Survey).

hydrological $\delta^{34} \mathrm{~S}$ values. Sulphur is leached from rocks into the ground and stream water and incorporated into the tissues of plants. The amount that is leached is dependent on the initial amount of sulphur and the mineral structure 
Table 1

Geological formations in and around Oxfordshire detailing the type of material and geological stage (information taken from BGS Geoindex).

\begin{tabular}{|c|c|c|c|c|c|}
\hline $\begin{array}{l}\text { Number } \\
\text { in Fig. } 2\end{array}$ & Lexicon & Lithology & Lithostrat & Age & BGSREF \\
\hline 1 & Lias group & $\begin{array}{l}\text { Mudstone, } \\
\text { siltstone, } \\
\text { limestone and } \\
\text { sandstone }\end{array}$ & $\begin{array}{l}\text { Lias group - mudstone, siltstone, limestone and } \\
\text { sandstone }\end{array}$ & Mesozoic & 545 \\
\hline 2 & Great oolite group & $\begin{array}{l}\text { Sandstone, } \\
\text { limestone and } \\
\text { argillaceous } \\
\text { rocks }\end{array}$ & $\begin{array}{l}\text { Great oolite group - sandstone, limestone and } \\
\text { argillaceous rocks }\end{array}$ & Bathonian & 201 \\
\hline 3 & $\begin{array}{l}\text { Kellaways formation and oxford } \\
\text { clay formation (undifferentiated) }\end{array}$ & $\begin{array}{l}\text { Mudstone, } \\
\text { siltstone and } \\
\text { sandstone }\end{array}$ & $\begin{array}{l}\text { Kellaways formation and oxford clay } \\
\text { formation (undifferentiated) - mudstone, } \\
\text { siltstone and sandstone }\end{array}$ & Jurassic & 334 \\
\hline 4 & Corallian group & $\begin{array}{l}\text { Limestone, } \\
\text { sandstone, } \\
\text { siltstone and } \\
\text { mudstone }\end{array}$ & $\begin{array}{l}\text { Corallian group - limestone, sandstone, } \\
\text { siltstone and mudstone }\end{array}$ & Oxfordian & 701 \\
\hline 5 & $\begin{array}{l}\text { West Walton formation, ampthill } \\
\text { clay formation and Kimmeridge } \\
\text { clay formation (undifferentiated) }\end{array}$ & $\begin{array}{l}\text { Mudstone, } \\
\text { siltstone and } \\
\text { sandstone }\end{array}$ & $\begin{array}{l}\text { West Walton formation, Ampthill clay } \\
\text { formation and Kimmeridge clay formation } \\
\text { (undifferentiated) - mudstone, sandstone and } \\
\text { limestone }\end{array}$ & $\begin{array}{l}\text { Upper } \\
\text { Jurassic }\end{array}$ & 213 \\
\hline 6 & $\begin{array}{l}\text { Gault formation and upper } \\
\text { greensand formation } \\
\text { (undifferentiated) }\end{array}$ & $\begin{array}{l}\text { Mudstone, } \\
\text { sandstone and } \\
\text { limestone }\end{array}$ & $\begin{array}{l}\text { Gault formation and upper greensand } \\
\text { formation (undifferentiated) - mudstone, } \\
\text { sandstone and limestone }\end{array}$ & Cretaceous & 490 \\
\hline 7 & Grey chalk subgroup & Chalk & Grey chalk subgroup - chalk & Cenomanian & 930 \\
\hline 8 & White chalk subgroup & Chalk & White chalk subgroup - chalk & $\begin{array}{l}\text { Upper } \\
\text { cretaceous }\end{array}$ & 720 \\
\hline 9 & Lambeth group & $\begin{array}{l}\text { Clay, silt, sand } \\
\text { and gravel }\end{array}$ & Lambeth group - clay, silt, sand and gravel & Paleocene & 704 \\
\hline 10 & Thames group & $\begin{array}{l}\text { Clay, silt, sand } \\
\text { and gravel }\end{array}$ & Thames group - clay, silt, sand and gravel & Eocene & 223 \\
\hline
\end{tabular}

in the rocks and soils (Scherer, 2009). Different forms of sulphur are bound in rocks: reduced sulphur as sulphides can be found mainly in pyrites, pyrrhotite, etc., whereas barites, gypsum, anhydrites contain oxidised sulphur as sulphates. Sulphates occur mainly as $\mathrm{SO}_{4}{ }^{2-}$ (Krouse and Mayer, 2000), whereas leached sulphides (e.g., pyrites) are often oxidised to sulphates (Hitchon and Krouse, 1972; Moncaster et al., 2000). Land plants incorporate sulphates from the groundwater/soil (Trust and Fry, 1992; Zhao and McGrath, 1994) and atmospheric sulphur such as $\mathrm{SO}_{2}$ and $\mathrm{H}_{2} \mathrm{~S}$ (Krouse, 1977; Gebauer et al., 1994; Agrawal, 2003).

Environmental sulphur isotope ratios $\left(\delta^{34} \mathrm{~S}\right.$ scaled against V-CDT standard) are known to be highly variable, and can range from $-50 \%$ to $+60 \%$ for inorganic sulphur compounds (Thode, 1991). Today, marine sulphate has a $\delta^{34} \mathrm{~S}$ value of $+20.3 \%$ (see Rees et al., 1978), but in the geological past it has ranged from $+10 \%$ to $+40 \%$ (Claypool et al., 1980). In contrast, terrestrial sulphides and sulphates of rocks range from $-40 \%$ to $+40 \%$ (Nielsen et al., 1991).

Unfortunately, there is only a limited amount of $\delta^{34} \mathrm{~S}$ data for geological and hydrological formations from the Oxfordshire region. Sulphates of marine sedimentary deposits from the Upper Jurassic range between $+15.4 \%$ to $+17.5 \%$ (Claypool et al., 1980) and marine sedimentary Cenozoic deposits of sulphates have values between
$+10.9 \%$ to $+25.5 \%$ (Claypool et al., 1980; Paytan et al., 1998). Fisher (1986), however, presented $\delta^{34} \mathrm{~S}$ data for the Upper Jurassic (Oxfordian) Oxford Clay from a pit in Warboys (Cambridgeshire) and found a low content of pyrites (average of $0.51 \%$ of sulphur) with highly ${ }^{34} \mathrm{~S}$-depleted ratios of approximately $-36.9 \%$. This pyritic (sulphide) sulphur isotope value represents a fractionation of approximately $-53 \%$ from the Jurassic seawater value of $+16 \%$ (Claypool et al., 1980). Such large sulphate-sulphide fractionation has been explained by Schwarcz and Burnie (1973) as a reduction of seawater sulphate under stationary conditions in an open system over a long period of time (Habicht and Canfield, 1997). However, the sulphates of the Oxford Clay analysed by Fisher (1986) resulted in $\delta^{34} \mathrm{~S}$ values of $+9.1 \%$. From these published results, it can be expected that terrestrial animals fed on vegetation grown on this Oxford Clay and aquatic animals from the River Thames should be different in their $\delta^{34} \mathrm{~S}$ values as the proportions of input of the sulphur sources varies between these environments.

\subsection{Isotope biochemistry}

Sulphur isotope ratios of terrestrial organic matter are reported to cover a range from $-20 \%$ to $+22 \%$ (Peterson 
and Fry, 1987), and a similar range is found for freshwater and marine fish (Hesslein et al., 1991). The total sulphur isotopic composition of plant matter has a range close to the local soil sulphur isotope ratio (Mekhtieva et al., 1976; Chukhrov et al., 1980; Trust and Fry, 1992). Therefore, sulphur isotopic signatures of animals and humans reflect a regional average of the biologically available sulphur isotope ratios of the soil (Krouse, 1989). This organically bound sulphur is passed along the food chain with a small fractionation factor of approximately $-1 \%$ (Peterson et al., 1985; Richards et al., 2003; Barnes and Jennings, 2007; Tanz and Schmidt, 2010).

In bone collagen, methionine is the only measurable sulphur containing amino acid (Neumann, 1949; Eastoe, 1955, 1967) and is classified as essential for animals and humans. Methionine can be synthesized from inorganic sulphur by plants (Noji and Saito, 2003; Hawkesford and de Kok, 2006), and herbivores and omnivores incorporate dietary plant methionine into their collagen. The $\delta^{34} \mathrm{~S}$ value of bone collagen thus represents an averaged sulphur isotopic signature of the local plants. Moreover, as bone collagen reflects an average isotopic signature over the last 10-20 years of life for an individual (Stenhouse and Baxter, 1979; Wild et al., 2000; Geyh, 2001; Hedges et al., 2007) the isotopic analysis of $\delta^{34} \mathrm{~S}$ values from archaeological populations yields a time averaged method to track migration and dietary patterns in archaeological populations.

Published sulphur isotope ratios of ancient human bone collagen range from $-5 \%$ to $+22 \%$ (Leach et al., 1996; Richards et al., 2001; Privat et al., 2007; Fornander et al., 2008; Linderholm et al., 2008a,b; Vika, 2009; Hu et al., 2009; Nehlich et al., 2010).

The only published $\delta^{34} \mathrm{~S}$ values for animals from Oxfordshire were presented by Richards et al. (2001), where in a pilot study they analysed modern specimens of a grey heron, a common hare, a stoat, and a pike (see Table 3 in Richards et al., 2001). Richards et al. (2001) suggested these modern animal results (ranging from $-11.6 \%$ to $-2.7 \%$ ) might have been diagenetically altered (due to modern day pollution), since they were more ${ }^{34} \mathrm{~S}$-depleted than archaeological human samples from central England (Gloucestershire and Worcestershire ranging from $+1.1 \%$ to $+13.7 \%$ ). However, the exact origin of these modern samples was unknown, and they might have originated from locations outside the Thames River Valley.

Recently, Leakey et al. (2008) studied carbon, nitrogen and sulphur isotope ratios of modern fish from the Thames Estuary and were able to isotopically distinguish between fish in coastal marine habitats from those in estuarine habitats. In addition, fish caught from upstream locations on the River Thames had more ${ }^{34} \mathrm{~S}$-depleted values than the fish caught at downstream locations and the results have a range of $-5 \%$ to $+17 \%$. The lowest sulphur isotope ratios were found as far inland as Kew, west of London (Fig. 1). The survey did not extend further upstream into the Oxford area so it is unknown what the $\delta^{34} \mathrm{~S}$ values of the water are in this portion of the River Thames. Nevertheless, the results of Leakey et al. (2008) are in agreement with the expected sulphur isotope ratios for the River Thames based on the published geochemical information.

\section{MATERIALS}

The material analysed for this study is summarised in Table 2, with species, age and sex (if available). The locations of all four archaeological sites from Oxfordshire, UK are shown in the inset in Fig. 1.

\subsection{Barrow Hills, Radley (1st-3rd centuries AD)}

The archaeological site of Barrow Hills, Radley is located about $2 \mathrm{~km}$ northeast of Abingdon and approximately $1.5 \mathrm{~km}$ north of the River Thames (Barclay and Halpin, 1997; Chambers and McAdam, 2007). Sulphur isotope ratios were analysed from cattle $(n=4)$, an aurochs $(n=1)$, and sheep $(n=2)$ and one of the cattle bones was radiocarbon dated to $1796 \pm 24 \mathrm{BP}$ (OxA-V-2260-32), which calibrates to 130-330 AD (95\% probability; calibrated with OxCal). The spatial proximity of this site (less than $10 \mathrm{~km}$ ) to the sites of Queenford Farm and Tubney Wood Quarry, and the similarity in ages allow these faunal samples to act as an ecological baseline for isotopic comparisons for the sites. As not all animal bones were radiocarbon dated there is the possibility that some of these animals might date to the Early Bronze Age period (since there are human remains from this time period found at Barrow Hills). This material is still relevant, since a chronological shift of the local sulphur isotopic composition would require a large spontaneous contribution of sulphur into the environment (e.g., volcanic eruption), for which there is no evidence.

\subsection{Tubney Wood Quarry, Tubney (2nd-6th centuries AD)}

Tubney Wood Quarry, Tubney is located approximately $15 \mathrm{~km}$ west from the site of Queenford Farm and excavations revealed two areas of Romano-British inhumations. Area 1 dates to the 2 nd century AD and area 2 represents a Late Roman period from the 4th to 6th century based on the associated pottery (Norton et al., 2007). The site is $2 \mathrm{~km}$ south of the River Thames on Corallian sands. Twelve humans were recovered from this location but only six of the individuals, two Romans (area 1) and four Late Romans (area 2), yielded enough collagen for $\delta^{34} \mathrm{~S}$ analysis. All of these skeletons were identified as adults and could represent the local Romano British population or immigrants. In addition, cattle $(n=3)$ and sheep-goat $(n=1)$ were also analysed.

\subsection{Queenford Farm, Dorchester-on-Thames (4th-6th centuries AD)}

The late/sub-Roman site of Queenford Farm (calibrated

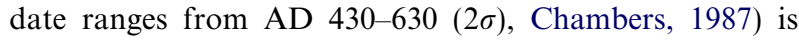
located to the north of the modern village of Dorchesteron-Thames, and on the right flood plain of the River Thame, approximately $1.8 \mathrm{~km}$ before it joins the River Thames in the south (Harman et al., 1978). Fuller et al. (2006a) analysed carbon and nitrogen isotope ratios of bone collagen from 87 of the 164 excavated individuals from the site of Queenford Farm, and were able to reconstruct dietary and weaning patterns from the late/sub-Roman period. This research 
Table 2

Summary of the bone collagen $\delta^{34} \mathrm{~S}$ results from Oxfordshire, UK (species, number of analysed specimens, mean values and standard deviation for sulphur isotope ratios and the amount percentages of sulphur in the samples).

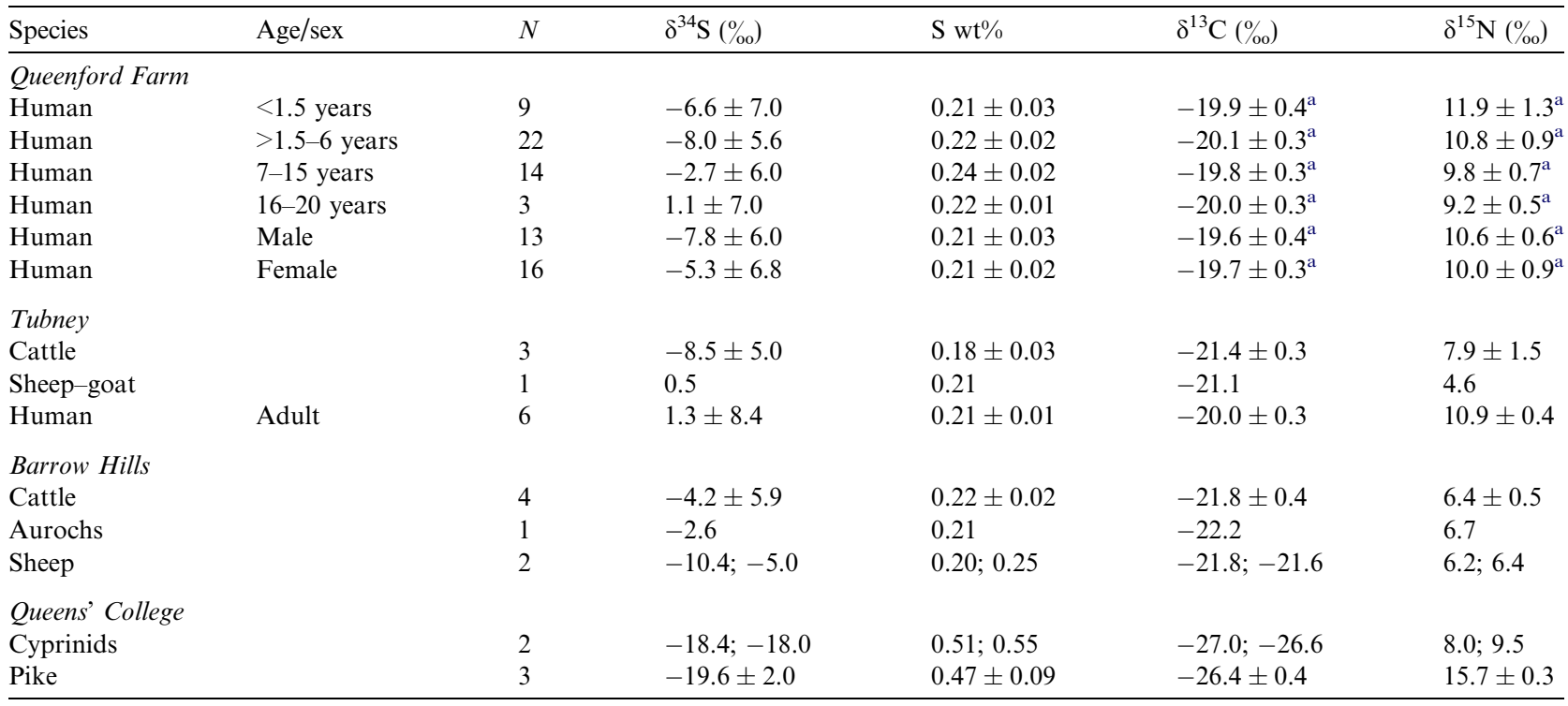

${ }^{a}$ Published by Fuller et al. (2006a).

found a statistical difference between males and females, where males tended to have had diets with higher nitrogen isotope ratios than the females (males $\delta^{15} \mathrm{~N} 10.6 \pm 0.5 \%$; females $\delta^{15} \mathrm{~N} 9.9 \pm 0.9 \%$ ). They also discovered that the range of the females' diet was broader (based on the standard deviation of their nitrogen isotope values) than that of the males. The infants and juveniles were slightly more ${ }^{13} \mathrm{C}$-depleted compared to the adults (females: $-19.7 \pm 0.3 \%$; males: $-19.5 \pm 0.4 \%$; infants and juveniles: $-20.2 \pm 0.3 \%$, and this indicated a weaning diet that was likely different from the adult population. The nitrogen isotope ratios indicated that weaning age was variable in this population, but that cessation of breastfeeding occurred between 3 and 4 years of age.

For this study, enough collagen for $\delta^{34} \mathrm{~S}$ analysis was extracted from 77 of the 87 bone samples used in the earlier work of Fuller et al. (2006a). The ages of the skeletons sampled for $\delta^{34} \mathrm{~S}$ measurements were as follows: neonates $(n=9)$ aged 1.5 years and below, infants $(n=22)$ aged greater than 1.5-6 years (infants I), children $(n=14)$ aged between 7 and 15 years old (infants II), juveniles $(n=3)$ aged between 15 and 20 years, and adult individuals $(n=29)$ greater than 20 years comprising 13 males and 16 females. No animal bones were recovered from Queenford Farm, so the $\delta^{34} \mathrm{~S}$ results were compared to material from the other sites which are located in the same general area and from similar time periods.

\subsection{Queens' College, Oxford University, Oxford (15th-16th centuries AD)}

Archaeological fish bone samples from the Thames River Valley during the Roman period could not be located for isotopic comparison to the archaeological sites surveyed in this project. Thus, fish bone samples from the mediaeval city of
Oxford have been used as an ecological baseline for the aquatic resources in this part of the Thames River Valley. During remodeling at Queens' College, Oxford University, the college's 15 th-century foundations were revealed and the refuse from college meals were recovered. The excavated layers date to approximately $1475-1550 \mathrm{AD}$ and several fish assemblages were identified. Specimens of local fish of the family Cyprinidae (probably Carp, $n=2$ ) and Esocidae ( $\hat{E}$ soxlucius, Pike less than $30 \mathrm{~cm}$ long, $n=3$ ) were analysed for $\delta^{34} \mathrm{~S}$ ratios. As these fish date to the pre-industrial period, the influence of anthropogenic sulphur contamination should be limited and therefore the $\delta^{34} \mathrm{~S}$ results should originate from the natural environment and thus be comparable to values during the Roman period of this area.

\section{METHODS}

\subsection{Extraction of bone collagen}

Bone collagen was extracted following the modified Longin method (Longin, 1971) reported by Richards and Hedges (1999). Bone pieces approximately 500-700 mg were used and surfaces were cleaned by air abrasion. The cleaned material was demineralised in $0.5 \mathrm{M} \mathrm{HCl}$ at $4{ }^{\circ} \mathrm{C}$ and the non-soluble content was heated in solution and denatured, particle filtered (EZEE-filter, cut-off $5 \mu \mathrm{m}$ ) and ultra-filtered (Amicon ultrafilter, cut-off $30 \mathrm{kDa}$ ) (Brown et al., 1988). The retained material was freeze dried and weighed for yield estimation.

\subsection{Carbon and nitrogen isotope ratio analyses}

For analyses of carbon and nitrogen isotope ratios, $0.5 \mathrm{mg}$ of purified bone collagen was weighed into tin capsules and combusted in an elemental analyser (Flash 
EA 2112, Thermo-Finnigan, Bremen, Germany) coupled to Delta XP isotope ratio mass spectrometer (Thermo-Finnigan, Bremen, Germany). The international standards IAEA $\mathrm{N} 1, \mathrm{~N} 2, \mathrm{CH} 6$ and $\mathrm{CH} 7$ and internal organic standards gave a standard deviation of better than $\pm 0.2 \%$.

\subsection{Sulphur isotope analysis}

For the analysis of sulphur isotope ratios, approximately $10 \mathrm{mg}$ of bone collagen combined with an additional $1 \mathrm{mg}$ $\mathrm{V}_{2} \mathrm{O}_{5}$ was weighed into tin capsules. The material was combusted to $\mathrm{SO}$ and $\mathrm{SO}_{2}$ gases using an elemental analyser (HeKaTech EuroVector, HeKaTech, Wegberg, Germany) which was coupled to a Delta $\mathrm{V}$ plus isotope ratio mass spectrometer (Thermo-Finnigan, Bremen, Germany). The international standards NBS127, IAEA S1, S2, S3, SO-5, IVA casein protein, and NIST1577b bovine liver gave a standard deviation of $\pm 0.4 \%$. Measurements of an internal laboratory standard of mammalian bone collagen had a standard deviation of $\pm 0.6 \%$, which is comparable to the standard error of the analysed archaeological material (Nehlich and Richards, 2009).

To measure the quality and the level of contamination in the $\delta^{34} \mathrm{~S}$ results, the sulphur content of the bone collagen is assessed. Following the criteria of Nehlich and Richards (2009) the amount of sulphur for well preserved collagen should be between $0.15 \%$ and $0.35 \%$ for mammalian bone collagen and between $0.4 \%$ and $0.8 \%$ for fish bone collagen. These specific ranges were established on bone collagen that was purified by ultrafiltration (cut-off $30 \mathrm{kDa}$ ), where only well preserved material was retained, and the degraded organic material and additional inorganic sulphur components were discarded.

\section{RESULTS AND DISCUSSION}

A summary of the isotopic results of the animals and humans from Oxfordshire are presented in Table 2, and individual $\delta^{34} \mathrm{~S}, \delta^{13} \mathrm{C}$, and $\delta^{15} \mathrm{~N}$ data with quality criteria are found in the Supplementary information (Table S1). The $\delta^{13} \mathrm{C}, \delta^{15} \mathrm{~N}$, and $\delta^{34} \mathrm{~S}$ values provided results which are within the accepted quality indicators suggested by DeNiro (1985), van Klinken (1999), and Nehlich and Richards (2009).

\subsection{Fish isotope results}

To estimate the sulphur isotopic composition of the preindustrial River Thames, local fish specimens (cyprinids and small pike) were analysed from the mediaeval site of Queens' College. The mean $\delta^{13} \mathrm{C}$ and $\delta^{15} \mathrm{~N}$ results of the cyprinids were $-26.8 \pm 0.2 \%$ and $8.8 \pm 0.8 \%$ and the mean $\delta^{13} \mathrm{C}$ and $\delta^{15} \mathrm{~N}$ results of the pike were $-26.4 \pm 0.4 \%$ and $15.7 \pm 0.3 \%$, respectively. The $\delta^{15} \mathrm{~N}$ values are in agreement with other published values for these species from mediaeval England (Müldner and Richards, 2005, 2007; Chenery et al., 2010). The highly ${ }^{13} \mathrm{C}$-depleted values of the fish specimens of $-26.6 \pm 0.5 \%$ are problematic, in that they differ significantly from the expected values of the Roman era food web as seen here and in previously published work (Müldner and Richards, 2005, 2007). One possible explanation for such low $\delta^{13} \mathrm{C}$ values could be a shift in baseline carbon isotope ratios of the riverine ecosystem from the Roman period to mediaeval times. Similarly ${ }^{13} \mathrm{C}$-depleted fish values were also found by Müldner and Richards $(2005,2007)$ in mediaeval York, which could indicate a general baseline carbon isotope shift over this period across England. Nevertheless, the sulphur isotope values should be unaffected between these time periods because the $\delta^{34} \mathrm{~S}$ ratio of the river is originating mainly from the geology which does not alter that rapidly.

The $\delta^{34} \mathrm{~S}$ results of the pike samples range from $-20.9 \%$ to $-17.3 \%$, and for the cyprinids the $\delta^{34} \mathrm{~S}$ values are $-18.4 \%$ and $-18.0 \%$. This $\delta^{34} \mathrm{~S}$ range of $3.5 \%$ is similar to the range of $\delta^{34} \mathrm{~S}$ values of fish from Neolithic sites along the River Danube (Nehlich et al., 2010). The biologically available $\delta^{34} \mathrm{~S}$ values of the River Thames at Oxford during the Middle Ages likely had a value of approximately $-18.8 \pm 1.4 \%$, and confirm that the terrestrial and aquatic ecosystems in Oxfordshire are distinct from each other in their bioavailable $\delta^{34} \mathrm{~S}$ values. These isotopic differences can thus be potentially used to distinguish between the terrestrial and aquatic dietary sources in the Roman populations of Tubney Wood Quarry and Queenford Farm.

The $\delta^{34} \mathrm{~S}$ results of the fish from the River Thames represent an average of the sulphur isotopic signature of the river water near the City of Oxford. This sulphur isotopic composition is unusually ${ }^{34} \mathrm{~S}$-depleted and suggests a high input of sulphur derived from sedimentary sulphides. The lowest $\delta^{34} \mathrm{~S}$ values of river sulphates from Europe were reported by Cortecci et al. (2002) from the River Arno, in Italy where $\delta^{34} \mathrm{~S}$ ratios as low as $-10.9 \%$ were found. Another example of highly ${ }^{34} \mathrm{~S}$-depleted ratios for riverine sulphur was reported by Hesslein et al. (1991). They found $\delta^{34} \mathrm{~S}$ values of fish tissues to be near $-18 \%$ in the Kukjuktuk Creek System in Canada. However, these ${ }^{34}$ S-depleted results from Italy and Canada are unique since the majority of analysed river sulphates and modern organic tissues from riverine ecosystems range between $-5 \%$ and $+10 \%$ (Jensen and Nakai, 1961; Ivanov, 1983; Grinenko and Krouse, 1992). In Oxfordshire the sulphur isotope ratio of the River Thames seems to be a mixture of shale sulphates with values of approximately $+9 \%$ and pyritic sulphides with average values of $-36.9 \%$ (Fisher, 1986). More research is needed in this area in terms of archaeological aquatic samples from different time periods and modern water samples to better understand the $\delta^{34} \mathrm{~S}$ results found in the Thames River Valley.

\subsection{Fauna isotope results}

Tubney Wood Quarry and Barrow Hills have similar carbon and nitrogen isotopic results. The cattle have mean $\delta^{13} \mathrm{C}$ and $\delta^{15} \mathrm{~N}$ values of $-21.6 \pm 0.5 \%$ and $7.1 \pm 1.4 \%$, the sheep/goats $-21.4 \pm 0.4 \%$ and $5.7 \pm 1.0 \%$, and the aurochs from Barrow Hills has a $\delta^{13} \mathrm{C}$ value of $-22.2 \%$ and a $\delta^{15} \mathrm{~N}$ value of $6.7 \%$. Although the $\delta^{13} \mathrm{C}$ values have a small range, the $\delta^{15} \mathrm{~N}$ values show more variation. This might be related either to different places of origin and trade of the livestock or that the animals were kept in a very 
diverse habitat, where the nitrogen isotopic signatures of the soil changed rapidly. Such a situation can be found close to rivers on floodplains, where riverine nitrogen is mixed with terrestrial nitrogen and therefore the soil can have various isotopic compositions (Thorp et al., 1998). Moreover, some of the animals sampled could be young unweaned animals and might have elevated $\delta^{15} \mathrm{~N}$ values.

As with the carbon and nitrogen results, the sulphur values from Tubney Wood Quarry and Barrow Hills are also similar. At Tubney Wood Quarry the $\delta^{34} \mathrm{~S}$ results range from $-13.5 \%$ for the cattle to $+0.5 \%$ for sheep-goats. At Barrow Hills, the $\delta^{34} \mathrm{~S}$ values of the cattle range from $-13.1 \%$ to $-0.6 \%$, the aurochs has a $\delta^{34} \mathrm{~S}$ value of $-2.6 \%$, and the sheep-goats have $\delta^{34} \mathrm{~S}$ values of $-10.4 \%$ and $-5.0 \%$. The faunal remains from the two sites have a large range $(-13.5 \%$ to $+0.5 \%)$ of values, and have the most ${ }^{34} \mathrm{~S}$-depleted signatures ever found in large mammals from an archaeological site (see Craig et al., 2006; Privat et al., 2007; Hu et al., 2009; Nehlich et al., 2010). Richards et al. (2001) also reported ${ }^{34} \mathrm{~S}$-depleted values, but for modern animals from Oxfordshire and interpreted these ${ }^{34} \mathrm{~S}$-depleted results as polluted by modern contaminants. However, in light of these results it is possible that the fauna reported in Richards et al. (2001) were not contaminated by anthropogenic sulphur given the fact that the archaeological remains analysed here (from different sites and burial conditions in Oxfordshire) have significantly ${ }^{34} \mathrm{~S}$ depleted values.

As the ${ }^{34} \mathrm{~S}$ isotope values in animal tissues are related to the environment where the animal lived and grazed, the large range of $\delta^{34} \mathrm{~S}$ values in the terrestrial animals is evidence of two isotopic divergent sulphur sources. It is likely that this is related to the geology and hydrology of the Thames River Valley and that the values could indicate that the terrestrial environment was regularly flooded by the River Thames (see inset in Fig. 1). These flooding events would add ${ }^{34} \mathrm{~S}$-depleted sulphates from the river to the terrestrial environment (which has higher ${ }^{34} \mathrm{~S}$ values) in varying degrees depending on location. Therefore, the $\delta^{34} \mathrm{~S}$ signatures of the terrestrial environment seem to be a mixture of riverine sulphur and locally available geological sulphur, and the amount of environmental ${ }^{34} \mathrm{~S}$-depletion is likely a function of the degree of riverine deposition. The incorporation of the local $\delta^{34} \mathrm{~S}$ values would therefore depend on the place of grazing of the animals. Animals that were fed on vegetation that was closer to the river likely had much lower $\delta^{34} \mathrm{~S}$ values than animals that grazed further away from the river or in areas that flooded less. Furthermore, the average $\delta^{34} \mathrm{~S}$ value of $-5.5 \%$ for the terrestrial animals is arguably a mixture of half terrestrial sulphur and half aquatic sulphur. However, the total sample size of the fauna in this study was small $(n=16)$; further studies from different areas in the Thames River Valley, may reveal that more ${ }^{34} \mathrm{~S}$-enriched values are found. Nevertheless, these $\delta^{34} \mathrm{~S}$ results and the large sulphur isotope range of the animals from Oxfordshire demonstrate how important archaeological sulphur isotope data are to evaluate ecosystems and highlight the influence that the geology has on the biology of a given locality.

\subsection{Human isotope results}

The mean carbon $(-19.7 \pm 0.4 \%$ oo $)$ and nitrogen $(10.4 \pm 0.8 \%$ ) isotope results of all the adult humans from Roman Oxfordshire indicate that the majority of the dietary protein was derived from herbivores with some possible inputs from freshwater resources. The isotopic results of the humans from Tubney are consistent with the earlier results published by Fuller et al. (2006a) for Queenford Farm (Figs. 3 and 4). These values are also similar to recently published data from other Roman period sites such as York and Gloucester in the UK (Müldner and Richards, 2007; Chenery et al., 2010), Öland in Sweden (Eriksson et al., 2008), and Italian sites at Velia (Craig et al., 2009) and Rome (Prowse et al., 2004; Rutgers et al., 2009).

The humans from Tubney have a $\delta^{34} \mathrm{~S}$ range from $-10.8 \%$ to $+9.6 \%$, with an average $\delta^{34} \mathrm{~S}$ value of $+1.3 \pm$ $8.4 \%$ (Fig. 4). Only two of the six humans fall within the range of the animal $\delta^{34} \mathrm{~S}$ values. The other individuals have ${ }^{34} \mathrm{~S}$-enriched values that suggest that they were either immigrants from other areas of Britain or the Roman Empire or the analysed animals do not represent the full biologically available $\delta^{34} \mathrm{~S}$ range of all terrestrial animals at Tubney. Future research involving strontium isotope analysis has the potential to provide more information about the place of origin of these individuals (Bentley, 2006).

The $\delta^{34} \mathrm{~S}$ values of the humans from Queenford Farm are similar to those from Tubney. Here the $\delta^{34} \mathrm{~S}$ values range from $-18.8 \%$ to $+6.8 \%$ and the humans have an average of $-5.9 \pm 6.6 \%$ (Figs. 3 and 4 ). The $\delta^{34} \mathrm{~S}$ results of the human bone collagen from these two sites in Oxfordshire have the largest range of $\delta^{34} \mathrm{~S}$ values ever found within an archaeological context. All the age groups from Queenford Farm show a similar range in $\delta^{34} \mathrm{~S}$ values, and most of the individuals correspond to the terrestrial animal $\delta^{34} \mathrm{~S}$ values from Oxfordshire. Nine humans $(<1.5$ years $(n=1)$, infants I $(n=3)$, infants II $(n=1)$, adult female $(n=2)$, adult male $(n=2)$ ) have $\delta^{34} \mathrm{~S}$ values lower than $-15 \%$, and this suggests diets with a high proportion of freshwater proteins (e.g., fish, shellfish, etc.) from the River Thames (Figs. 3 and 4). In contrast to the $\delta^{15} \mathrm{~N}$ results reported in Fuller et al. (2006a), no significant differences in the mean $\delta^{34} \mathrm{~S}$ values were observed between the males $(-7.8 \pm 6.3 \%$ o and females $(-5.3 \pm 7.0 \%)$.

The findings of this current research are somewhat different to the results of Müldner and Richards (2007) and Chenery et al. (2010) where ${ }^{15} \mathrm{~N}$-enriched values were argued to reflect marine protein consumption. At Tubney Wood Quarry and Queenford Farm the high $\delta^{15} \mathrm{~N}$ values coincide with low $\delta^{34} \mathrm{~S}$ values indicating the consumption of freshwater protein resources. In writing about dietary habits in Roman Britain, Cool (2006) stated that settlements close to the sea have a significant number of marine fish species in the archaeological record, whereas inland sites have mixtures of marine and freshwater species. Further, it was suggested that the dietary proportion of fish in Romano-Britain was small. These $\delta^{34} \mathrm{~S}$ isotopic results indicate much more variability in the dining habits of inhabitants from Roman Oxfordshire than previously 


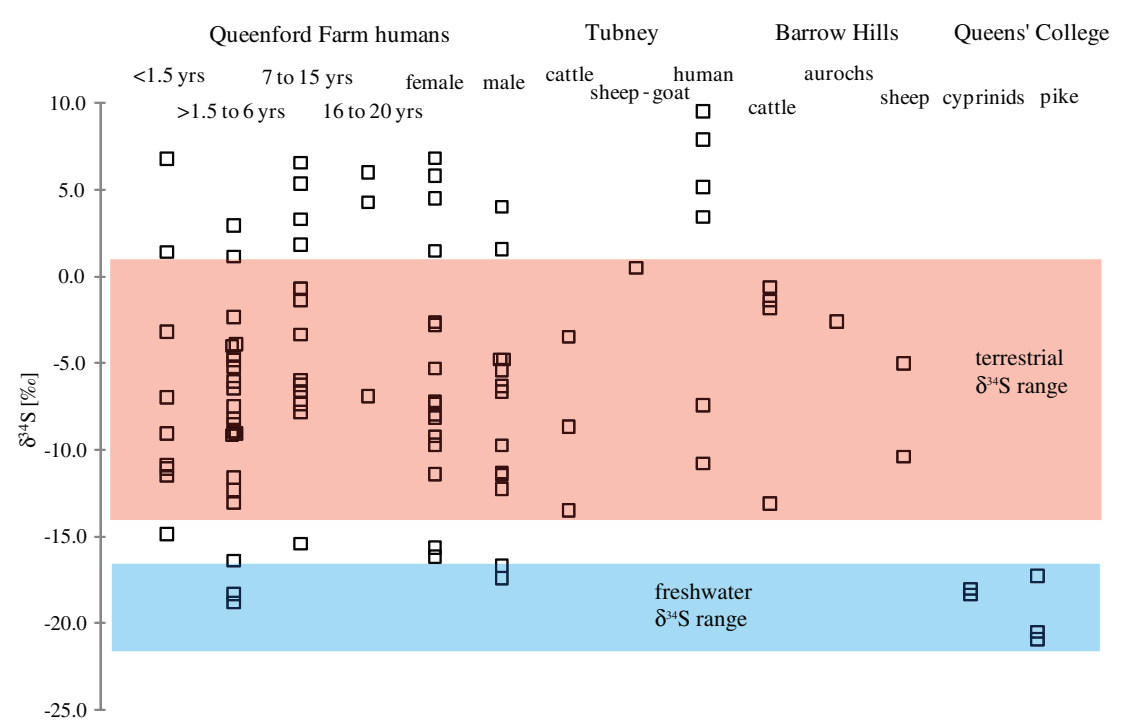

Fig. 3. $\delta^{34} \mathrm{~S}$ values of bone collagen of animals and humans from Oxfordshire. The darkened boxes show the $\delta^{34} \mathrm{~S}$ ranges for the terrestrial and the aquatic environment.

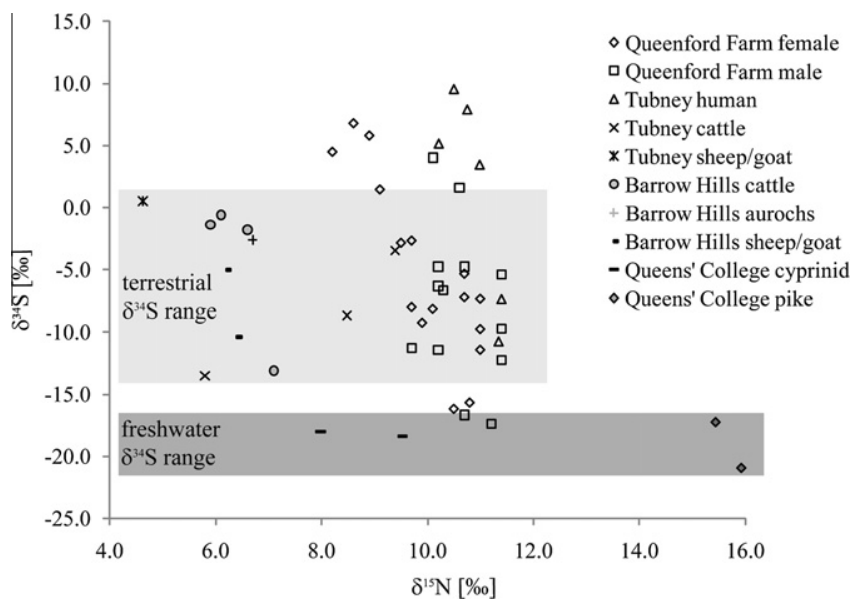

Fig. 4. Plot of sulphur and nitrogen isotope values of adult humans and associated fauna from Oxfordshire.

thought, with some individuals eating no fish and others showing a diet almost exclusively based on freshwater protein such as fish. Such large dietary variability is not visible by analysing carbon and nitrogen isotopes only. Finally, the wide range of $\delta^{34} \mathrm{~S}$ values observed in the humans from Oxfordshire implies a large range of $\delta^{34} \mathrm{~S}$ values in the natural environment in this region. This variability of the biologically available sulphur isotopic signatures in ancient Oxfordshire has its origin in the geological formations of this area, for example the depleted ${ }^{34} \mathrm{~S}$ values of the fish analysed here and the published ${ }^{34} \mathrm{~S}$-depleted values for sulphides of the Oxford Clay deposits are a good indication that the sulphides are highly influencing the aquatic ecosystem in the Thames River Valley (Fisher, 1986).

\subsection{Breastfeeding and weaning patterns at Queenford Farm}

Previous research by Fuller et al. (2006a) examined breastfeeding and weaning patterns at Queenford Farm by using $\delta^{13} \mathrm{C}$ and $\delta^{15} \mathrm{~N}$ values. That study found that infants between 2 and 4 years of age had ${ }^{13} \mathrm{C}$-depleted values which were interpreted as the consumption of a unique weaning diet that was more $\mathrm{C}_{3}$-terrestrial in origin and possibly cereal based (Fig. 5a). The $\delta^{15} \mathrm{~N}$ values indicated that the cessation of breastfeeding was variable, but that weaning was a gradual process occurring between the ages of 2 4 years (Fig. $5 b$ ).

The $\delta^{34} \mathrm{~S}$ results for the infants and children from Queenford Farm are presented in Fig. 5c and the data are summarized in Table 2. As there is believed to be only a small trophic level effect in sulphur isotope ratios, $-0.5 \%$ o to $-1.0 \%$ from diet to consumer (Richards et al., 2003; Barnes and Jennings, 2007), we anticipated that the $\delta^{34} \mathrm{~S}$ values in combination with $\delta^{15} \mathrm{~N}$ values might be a better indicator of the weaning foods consumed by these infants and children. Like the adults, the $\delta^{34} \mathrm{~S}$ results of the infants, children, and juveniles show a wide range of values $(-18.8 \%$ to $+6.8 \%)$. No ${ }^{34}$ S-enrichment pattern of 

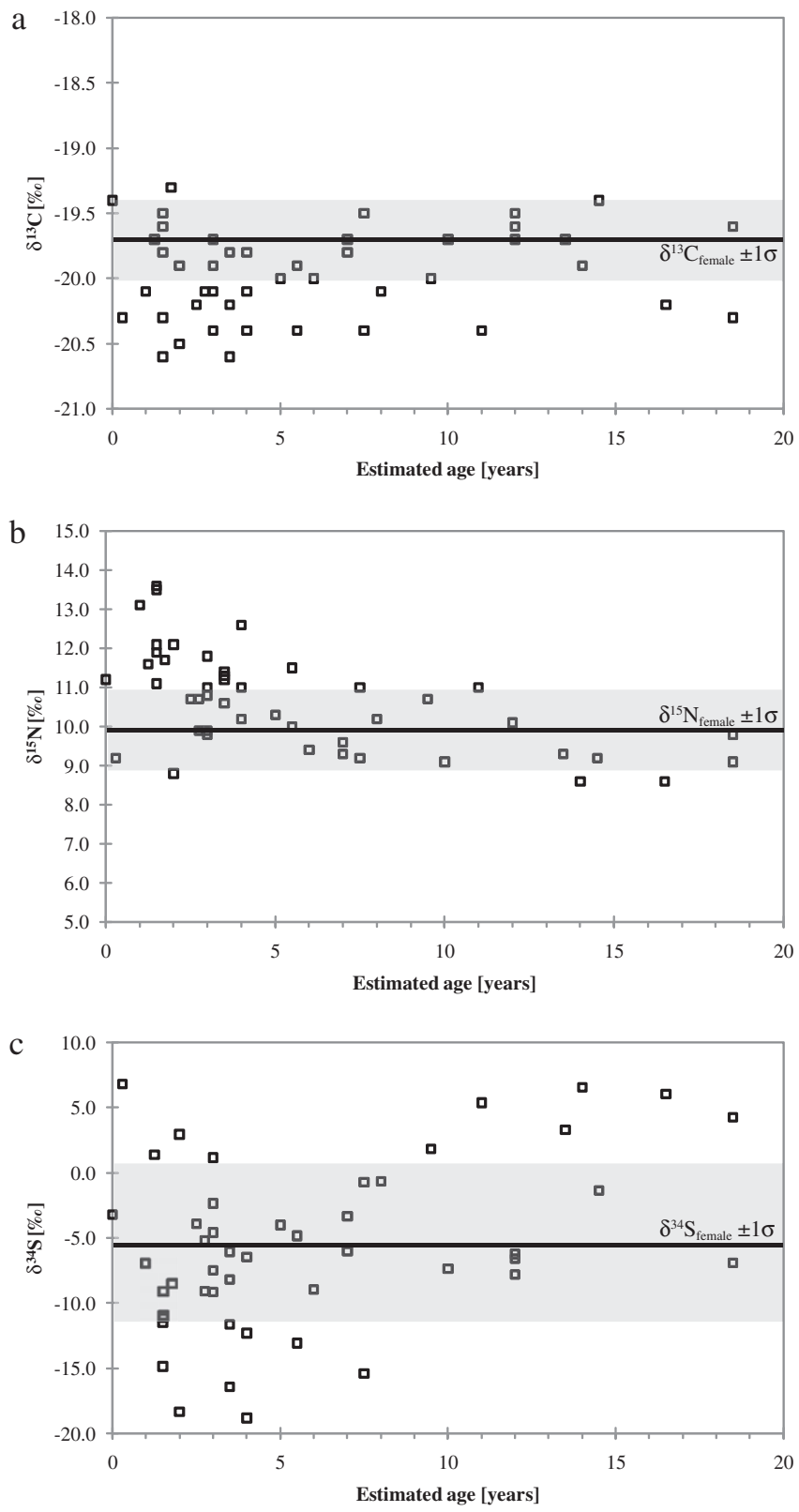

Fig. 5. (a-c) $\delta^{13} \mathrm{C}, \delta^{15} \mathrm{~N}$, and $\delta^{34} \mathrm{~S}$ values for infants and juveniles plotted against age at death. The horizontal line represents the female average and the grey box \pm 1 standard deviation. $\delta^{13} \mathrm{C}$ and $\delta^{15} \mathrm{~N}$ data taken from Fuller et al. (2006a).

breastfeeding is observed in the $\delta^{34} \mathrm{~S}$ results of the infants. However, as with the $\delta^{13} \mathrm{C}$ data, the $\delta^{34} \mathrm{~S}$ results have the lowest values between the ages of 2-4 years at Queenford Farm (Fig. 5a and c). These ${ }^{34} \mathrm{~S}$-depleted results are similar to the $\delta^{34} \mathrm{~S}$ values obtained from the freshwater fish and indicate that the unique weaning diet found with the $\delta^{13} \mathrm{C}$ results in Fuller et al. (2006a) was likely the result of freshwater protein consumption or cereals coming from freshwater influenced areas (Fuller et al., 2004, 2005). This is clearly illustrated for the five individuals with $\delta^{34} \mathrm{~S}$ values below $-15 \%$ (Fig. 5 c), although there are also newborns with high $\delta^{34} \mathrm{~S}$ values. The older children and all of the individuals between 8 and 18 years have more ${ }^{34}$ S-enriched values indicating that they were eating diets based mainly on terrestrial protein.

This research is the first to use $\delta^{34} \mathrm{~S}$ values to examine archaeological breastfeeding and weaning patterns and firmly establishes the benefits that $\delta^{34} \mathrm{~S}$ results can provide in dietary reconstructions. The information provided by $\delta^{34} \mathrm{~S}$ analysis is especially relevant to sites that border freshwater lakes or rivers or where there is evidence of freshwater resource consumption, like the sites of Tubney and Queenford Farm that are located in the Thames River Valley. Since the consumption of freshwater protein resources such as fish will result in elevated $\delta^{15} \mathrm{~N}$ values, it was difficult to determine that they were part of the weaning diet 


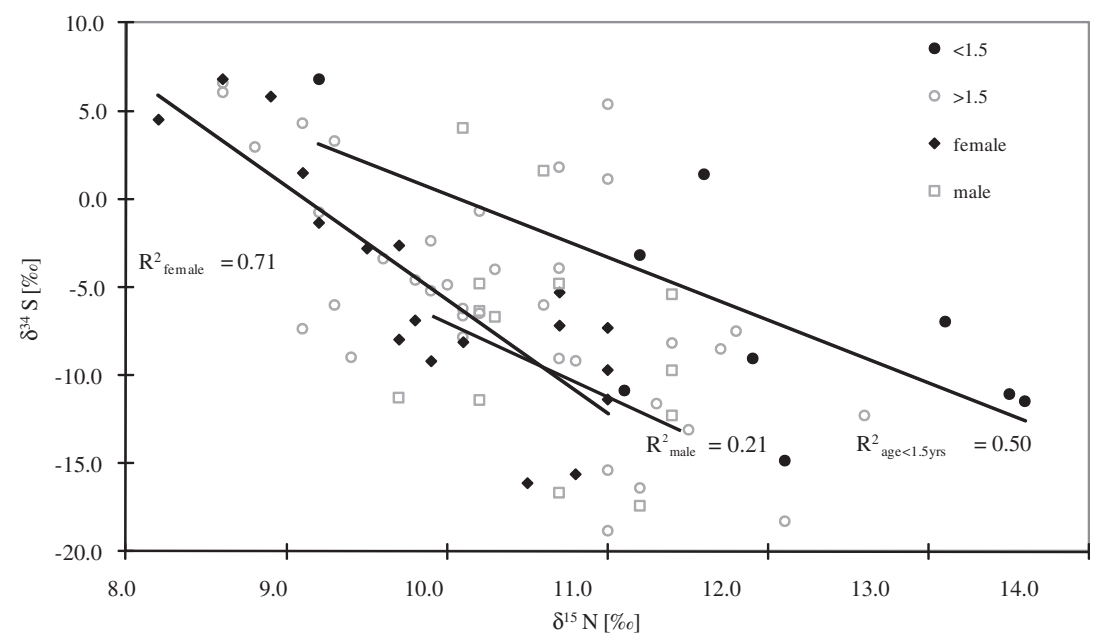

Fig. 6. Plot of $\delta^{34} \mathrm{~S}$ and $\delta^{15} \mathrm{~N}$ isotope values of humans from Queenford Farm, classified by age and sex with regression lines for males, females, and babies below 1.5 years age.

using only the $\delta^{13} \mathrm{C}$ and $\delta^{15} \mathrm{~N}$ results, as the high $\delta^{15} \mathrm{~N}$ values can be interpreted as breast milk in the diet. Thus, this important finding was only made accessible by the combination of $\delta^{34} \mathrm{~S}$ analysis with the $\delta^{13} \mathrm{C}$ and $\delta^{15} \mathrm{~N}$ results. It is interesting to note that the strongest evidence for freshwater influenced protein (fish, birds, plants from the floodplain) consumption occurs during the weaning period and not during later childhood or during adolescence for the individuals at Queenford Farm. Was this feeding strategy related to status, economics, personal dietary preferences, or a societal belief concerning the nutritional benefits of riverine protein resources for infants during the weaning period? It is difficult to speculate if one or a combination of reasons led to this unique weaning diet, but apart from four adult individuals (Fig. 4) there is little evidence for significant freshwater influenced protein consumption in the Queenford Farm population. However, there is a linear correlation $\left(R^{2}=0.71 ; p<0.0001\right)$ between the $\delta^{15} \mathrm{~N}$ and $\delta^{34} \mathrm{~S}$ values of the females at Queenford Farm indicating that they consumed terrestrial food which was heavily influenced by freshwater sulphur from the nearby river, and that there was a gradient in the consumption of these resources by the females (Fig. 6). A weak linear trend $\left(R^{2}=0.5\right)$ between the $\delta^{15} \mathrm{~N}$ and $\delta^{34} \mathrm{~S}$ results is also observed for the infants ( $\leqslant 1.5$ years) that is offset by a ${ }^{15} \mathrm{~N}$ enrichment of up to $\sim 2.5 \%$. This suggests that these youngest infants were obtaining their sulphur isotopic values from their mothers in the form of breast milk and not necessarily from the direct ingestion of terrestrial or freshwater protein. This linear correlation is not found in the males $\left(R^{2}=0.21\right)$ from Queenford Farm suggesting that they had greater variation in their diets than just the terrestrial and freshwater protein sources. Finally, it is important to point out that the infants and children span the entire period (100-200 years) of the cemetery at Queenford Farm, and that the observation of a terrestrial and/or freshwater based weaning diet may reflect a temporal rather than overall pattern in how children were raised and cared for in the population.
Fuller et al. (2006a) constructed a mortality profile for all of the infants and juveniles recovered from Queenford Farm and found that the highest number of child deaths were between the ages of 2-3 years, which corresponded to the time of weaning from the carbon and nitrogen isotopic results. The transition from breast milk to solid foods is a vulnerable period for infants and children, and is associated with an increased risk of mortality and morbidity by decreased levels of immunity and an increase in exposure to pathogens and nutritional stress (Knodel and Kintner, 1977; Katzenberg et al., 1996). As the greatest consumption of freshwater influenced protein resources is primarily found during the weaning period, it is possible that this unique diet might have played a role in the high infant mortality observed between the ages of 2-4 years at Queenford Farm. While it is speculative at this point to link the specific consumption of such a diet to elevated infant mortality, it is likely that the general weaning diet was possibly inadequate in terms of nutrition compared to breast milk, and contaminated with disease causing agents. Katzenberg et al. (1996) noted similar mortality patterns in societies where sanitation and hygiene are poor. Future research that examines the isotopic dietary patterns in tooth dentine serial sections (ex. Fuller et al., 2003) from individuals that survived the weaning period could help establish if there was a link between the type of weaning diet and the survivability of these individuals.

\section{CONCLUSIONS}

This research represents the largest and most detailed application of $\delta^{34} \mathrm{~S}$ measurements to examine dietary practices during the Romano-British Period, and the first use of $\delta^{34} \mathrm{~S}$ values to determine breastfeeding and weaning practices in an archaeological population. In particular, this study focused on how $\delta^{34} \mathrm{~S}$ results can provide more information for dietary reconstruction when used together with $\delta^{13} \mathrm{C}$ and $\delta^{15} \mathrm{~N}$ values, especially in regards to the detection of the consumption of freshwater protein resources. It was 
found that the $\delta^{34} \mathrm{~S}$ results from the terrestrial environment were highly variable $(-13.6 \%$ to $+0.5 \%)$, but that the $\delta^{34} \mathrm{~S}$ signatures of the aquatic ecosystem were narrower $(-20.9 \%$ to $-17.3 \%)$ and highly ${ }^{34} \mathrm{~S}$-depleted. These results suggest that sulphates and sulphides from the river were deposited on the land during flooding events. The humans from the sites of Tubney Wood Quarry and Queenford Farm display the largest range $(-18.8 \%$ to $+9.6 \%)$ of $\delta^{34} \mathrm{~S}$ values from any archaeological context to date. The $\delta^{34} \mathrm{~S}$ values in combination with the $\delta^{13} \mathrm{C}$ and $\delta^{15} \mathrm{~N}$ values show that some individuals, but not the population as a whole, clearly had a diet that was based predominately on freshwater influenced protein resources such as fish, birds or crops growing on the floodplains of the river. While no difference was found for the mean $\delta^{34} \mathrm{~S}$ values between the sexes, the females from Queenford Farm displayed a linear correlation $\left(R^{2}=0.71\right)$ between their $\delta^{15} \mathrm{~N}$ and $\delta^{34} \mathrm{~S}$ results. These results represent the first direct isotopic evidence for the consumption of a freshwater protein diet in Roman Britain, and highlight the important role that $\delta^{34} \mathrm{~S}$ analysis can play in palaeodietary reconstruction.

The $\delta^{34} \mathrm{~S}$ analysis of the infants and children revealed that the unique weaning diet between the ages of 2-4 years proposed by Fuller et al. (2006a) on the basis of the $\delta^{13} \mathrm{C}$ results was in fact likely the result of the consumption of freshwater influenced protein resources. The older children and all of the individuals aged between 8 and 18 years of age have terrestrial dietary signatures and show little evidence for the consumption of any freshwater influenced protein in their diets. It is unclear why infants during the Romano-British Period were weaned onto a diet that likely included riverine fish or cereals originating from areas heavily influenced by freshwater sulphur, but this may have been the result of factors such as status, economics, access and personal dietary preference by families, or a societal belief in the potential nutritional value of freshwater protein resources. More isotopic research is needed from other Roman era sites in the UK to conclude if this unique infant and child dietary practice is limited to Queenford Farm or reflects the period as a whole.

In conclusion, the $\delta^{34} \mathrm{~S}$ data from this study are supported by published hydrological and geochemical values and in particular data from the Oxford Clay formation. The River Thames cuts through this geological formation and leaches sulphur from these rocks into the ground and stream water, and this accounts for the highly ${ }^{34} \mathrm{~S}$-depleted signatures found in the humans and animals. While much more $\delta^{34} \mathrm{~S}$ analysis is needed from the Thames River Valley, this research shows how isotopic knowledge of the geosphere, hydrosphere and biosphere aid in the correct interpretation of the mammalian and human $\delta^{34} \mathrm{~S}$ food web values.

\section{ACKNOWLEDGEMENTS}

This research was funded by the Max-Planck Society. We thank Lauren Gilmour for providing access to the Queenford Farm skeletal material and Andrew Norton (Oxford Archaeology) for providing access to the Tubney material. The radiocarbon date on the Barrow Hills animal bone was obtained as part of the Beaker People Project funded by the Arts and Humanities Research
Council (UK). Further, we thank two anonymous referees and Simon Bottrell for very insightful reviews and comments to the manuscript, helping to improve it.

\section{APPENDIX A. SUPPLEMENTARY DATA}

Supplementary data associated with this article can be found, in the online version, at doi:10.1016/ j.gca.2011.06.009.

\section{REFERENCES}

Agrawal M. (2003) Plant responses to atmospheric sulphur. In Sulphur in Plants (eds. Y. P. Abrol and A. Ahmad). Kluwer Academic Publishers, Dordrecht, pp. 279-293.

Arkell W. J. (1947) The Geology of Oxford. Clarendon Press, Oxford.

Barclay A and Halpin C (1997) Excavations at Barrow Hills, Radley, Oxfordshire. In The Neolithic and Bronze Age Monument Complex. Oxford Archaeological Unit, Oxford. pp. 1-7.

Barnes C. and Jennings S. (2007) Effect of temperature, ration, body size and age on sulphur isotope fractionation in fish. Rapid Commun. Mass Spectrom. 21, 1461-1467.

Bentley R. A. (2006) Strontium isotopes from the earth to the archaeological skeleton: a review. J. Archaeol. Method Theory 13, 135-187.

Bridgland D. R. (1994) Quaternary of the Thames. Chapman \& Hall, London.

Bridgland D. R. and D'Olier B. (1995) The Pleistocene evolution of the Thames and Rhine drainage systems in the southern North Sea Basin. In Island Britain: a Quaternary Perspective (ed. R. C. Preece). Geological Society Special Publication, pp. 27-45.

Brown T., Nelson D., Vogel J. and Southon J. (1988) Improved collagen extraction by modified Longin method. Radiocarbon 30, 171-177.

Chambers R. A. (1987) The late- and sub-Roman cemetery at Queenford Farm, Dorchester-on-Thames, Oxon. Oxoniensia 54, 35-69.

Chambers R. and McAdam E. (2007) Excavations at Barrow Hills, Radley, Oxfordshire, 1983-5. Vol. 2: The Romano-Britissh Cemetery and ANglo-Saxon Settlement. Thames Valley Landscapes Monograph 25. Oxford Archaeology, Oxford.

Chenery C., Müldner G., Evans J., Eckardt H. and Lewis M. (2010) Strontium and stable isotope evidence for diet and mobility in Roman Gloucester, UK. J. Archaeol. Sci. 37, 150 163.

Chukhrov F. V., Ermilova L. P., Churikov V. S. and Nosik L. P. (1980) The isotopic composition of plant sulfur. Org. Geochem. 2, 69-75.

Claypool G. E., Holser W. T., Kaplan I. R., Sakai H. and Zak I. (1980) The age curves of sulfur and oxygen isotopes in marine sulfate and their mutual interpretation. Chem. Geol. 28, 199260.

Cool H. E. M. (2006) Eating and Drinking in Roman Britain. Cambridge University Press, Cambridge.

Cortecci G., Dinelli E., Bencini A., Adorni-Braccesi A. and La Ruffa G. (2002) Natural and anthropogenic $\mathrm{SO}_{4}$ sources in the Arno river catchment, northern Tuscany, Italy: a chemical and isotopic reconnaissance. Appl. Geochem. 17, 79-92.

Coulson J. P., Bottrell S. H. and Lee J. A. (2005) Recreating atmospheric sulphur deposition histories from peat stratigraphy: diagenetic conditions required for signal preservation and reconstruction of past sulphur deposition in the Derbyshire Peak District, UK. Chem. Geol. 218, 223-248. 
Craig O. E., Ross R., Andersen S. H., Milner N. and Bailey G. N. (2006) Focus: sulphur isotope variation in archaeological marine fauna from northern Europe. J. Archaeol. Sci. 33, $1642-1646$.

Craig O. E., Biazzo M., O'Connell T. C., Garnsey P., MartinezLabarga C., Lelli R., Salvadei L., Tartaglia G., Nava A., Renò L., Fiammenghi A., Rickards O. and Bondioli L. (2009) Stable isotopic evidence for diet at the Imperial Roman coastal site of Velia (1st and 2nd Centuries AD) in Southern Italy. Am. J. Phys. Anthropol. 139, 572-583.

DeNiro M. J. (1985) Postmortem preservation and alteration of in vivo bone collagen isotope ratios in relation to palaeodietary reconstruction. Nature 317, 806-809.

Eastoe J. E. (1955) The amino acid composition of mammalian collagen and gelatin. Biochem. J. 61, 589-600.

Eastoe J. E. (1967) Composition of collagen and allied proteins. In Treatise on Collagen (ed. G. N. Ramachandran). Academic Press, London, pp. 1-72.

Eriksson G., Linderholm A., Fornander E., Kanstrup M., Schoultz P., Olofsson H. and Lidén K. (2008) Same island, different diet: cultural evolution of food practice on Öland, Sweden, from the Mesolithic to the Roman Period. J. Anthropol. Archaeol. 27, $520-543$.

Fisher I. S. J. (1986) Pyrite formation in bioturbated clays from the Jurassic of Britain. Geochim. Cosmochim. Acta 50, 517-523.

Fogel M. L., Tuross N., Owsley D. W. (1989) Nitrogen isotope tracers of human lactation in modern and archaeological populations. Annual Report of the Director of the Geophysical Laboratory. Carnegie Institution, Washington, 1988-1989, pp. $111-117$.

Fornander E., Eriksson G. and Liden K. (2008) Wild at heart: approaching pitted ware identity, economy and cosmology through stable isotopes in skeletal material from the Neolithic site Korsnäs in Eastern Central Sweden. J. Anthropol. Archaeol. 27, 281-297.

Fuller B. T., Richards M. P. and Mays S. A. (2003) Stable carbon and nitrogen isotope variations in tooth dentine serial sections from Wharram Percy. J. Archaeol. Sci. 30, 1673-1684.

Fuller B. T., Fuller J. L., Sage N. E., Harris D. A., O'Connell T. C. and Hedges R. E. M. (2004) Nitrogen balance and $\delta^{15} \mathrm{~N}$ : why you're not what you eat during pregnancy. Rapid Commun. Mass Spectrom. 18, 2889-2896.

Fuller B. T., Fuller J. L., Sage N. E., Harris D. A., O'Connell T. C. and Hedges R. E. M. (2005) Nitrogen balance and $\delta^{15} \mathrm{~N}$ : why you're not what you eat during nutritional stress. Rapid Commun. Mass Spectrom. 19, 2497-2506.

Fuller B. T., Molleson T. I., Harris D. A., Gilmour L. T. and Hedges R. E. M. (2006a) Isotopic evidence for breastfeeding and possible adult dietary differences from late/sub-Roman Britain. Am. J. Phys. Anthropol. 129, 45-54.

Fuller B. T., Fuller J. L., Harris D. A. and Hedges R. E. M. (2006b) Detection of breastfeeding and weaning in modern human infants with carbon and nitrogen stable isotope ratios. Am. J. Phys. Anthropol. 129, 279-293.

Gebauer G., Giesemann A., Schulze E. and Jäger H. (1994) Isotope ratios and concentrations of sulfur and nitrogen in needles and soils of Picea abies stands as influenced by atmospheric deposition of sulfur and nitrogen compounds. Plant Soil 164, 267-281.

Geyh M. A. (2001) Bomb radiocarbon dating of animal tissue and hair. Radiocarbon 43, 723-730.

Gibbard P. L., Rose J. and Bridgland D. R. (1988) The history of the great Northwest European rivers during the past three million years [and discussion]. Philos. Trans. R. Soc. B-Biol. Sci. 318, 559-602.
Giesemann A. J. H., Norman A. L., Krouse H. R. and Brand W. A. (1994) On-line sulfur-isotope determination using an elemental analyzer coupled to a mass spectrometer. Anal. Chem. 66, 2816-2819.

Grinenko V. A. and Krouse H. R. (1992) Isotope data on the nature of riverine sulfates. Mitteilungen des Geologisch-Paläontologischen Institutes 72, 9-18.

Habicht K. S. and Canfield D. E. (1997) Sulfur isotope fractionation during bacterial sulfate reduction in organic-rich sediments. Geochim. Cosmochim. Acta 61, 5351-5361.

Harman M., Lambrick G., Miles D. and Rowley T. (1978) Roman burials around Dorchester-on-Thames. Oxoniensia XLIII, 116.

Hawkesford M. J. and de Kok L. J. (2006) Managing sulphur metabolism in plants. Plant, Cell Environ. 29, 382-395.

Hedges R. E. M., Clement J. G., Thomas C. D. L. and O'Connell T. C. (2007) Collagen turnover in the adult femoral mid-shaft: modeled from anthropogenic radiocarbon tracer measurements. Am. J. Phys. Anthropol. 133, 808-816.

Hesslein R. H., Capel M. J., Fox D. E. and Hallard K. A. (1991) Stable isotopes of sulfur, carbon, and nitrogen as indicator of trophic level and fish migration in the Lower Mackenzie River Basin, Canada. Can. J. Fish. Aquat. Sci. 48, 2258-2265.

Hitchon B. and Krouse H. R. (1972) Hydrogeochemistry of the surface waters of the Mackenzie River drainage basin, Canada - III. Stable isotopes of oxygen, carbon and sulphur. Geochim. Cosmochim. Acta 36, 1337-1357.

Hobson K. A. (1999) Tracing origins and migration of wildlife using stable isotopes: a review. Oecologia 120, 314-326.

Hu Y., Shang H., Tong H., Nehlich O., Liu W., Zhao C., Yu J., Wang C., Trinkaus E. and Richards M. P. (2009) Stable isotope dietary analysis of the Tianyuan 1 early modern human. Proc. Natl. Acad. Sci. USA 106, 10971-10974.

Ivanov M. V. (1983) The sulphur cycle in continental reservoirs. In The Global Biogeochemical Sulphur Cycle-Scope, vol. 39 (eds. M. V. Ivanov and J. R. Freney). Scientific Committee on Problems of the Environment, pp. 297-356.

Jarvie H. P., Lycett E., Neal C. and Love A. (2002) Patterns in nutrient concentrations and biological quality indices across the upper Thames river basin, UK. Sci. Total Environ. 282-283, 263-294.

Jeans C. V. (2006) Clay mineralogy of the Jurassic strata of the British Isles. Clay Mineral. 41, 187-307.

Jensen M. L. and Nakai N. (1961) Sources and isotopic composition of atmospheric sulfur. Science 134, 2102-2104.

Katzenberg M. A., Herring D. A. and Saunders S. R. (1996) Weaning and infant mortality: evaluating the skeletal evidence. Yearbook Phys. Anthropol. 39, 177-199.

Kester C. L., Rye R. O., Johnson C. A., Schwartz C. and Holmes C. (2001) On-line sulfur isotope analysis of organic material by direct combustion. Isotopes Environ. Health Stud. 37, 53-65.

Kinniburgh D. G. and Beckett P. H. T. (1983) Geochemical mapping in Oxfordshire: a comparison of stream sediment and soil sampling. J. Soil Sci. 34, 183-203.

Knodel J. and Kintner H. (1977) The impact of breastfeeding patterns on the biometric analysis of infant mortality. Demography 14, 391-409.

Krouse H. R. (1977) Sulphur isotope abundance elucidate uptake of atmospheric sulphur emissions by vegetation. Nature $\mathbf{2 6 5}$, 45-46.

Krouse H. R. and Levinson A. A. (1984) Geographical trends of carbon and sulphur isotope abundances in human kidney stones. Geochim. Cosmochim. Acta 48, 187-191.

Krouse H. R. and Mayer B. (2000) Sulphur and oxygen isotopes in sulphate. In Environmental Tracers in Subsurface Hydrology 
(eds. P. G. Cook and A. L. Herczeg). Kluwer Academic Publisher, Dordrecht, pp. 195-231.

Krouse R. H. (1989) Sulfur isotope studies of the pedosphere and biosphere. In Stable Isotopes in Ecological Research (eds. P. Rundel, J. Ehleringer and K. Nagy). Springer, New York, pp. 424-444.

Leach B. F., Quinn C. J. and Lyon G. L. (1996) A stochastic approach to the reconstruction of prehistoric human diet in the Pacific region from bone isotope signatures. Tuhinga: Records of the Museum of New Zealand Te Papa Tongarewa 8, 1-54.

Leakey C. D., Attrill M. J., Jennings S. and Fitzsimons M. F. (2008) Stable isotopes in juvenile marine fishes and their invertebrate prey from the Thames Estuary, UK, and adjacent coastal regions. Estuar. Coast. Shelf Sci. 77, 513-522.

Linderholm A., Andersson K., Mörth C., Grundberg L., Harding B. and Liden K. (2008a) An early Christian cemetery at Björned in northern Sweden. Fornvännen 103, 176-189.

Linderholm A., Jonson C. H., Svensk O. and Liden K. (2008b) Diet and status in Birka: stable isotopes and grave goods compared. Antiquity 82, 446-461.

Longin R. (1971) New method of collagen extraction for radiocarbon dating. Nature 230, 241-242.

McArdle N., Liss P. and Dennis P. (1998) An isotopic study of atmospheric sulphur at three sites in Wales and at Mace Head Eire. J. Geophys. Res. 103, 31079-31094.

Mekhtieva V. L., Gavrilov E. Y. and Pankina R. G. (1976) Sulfur isotopic composition in land plants. Geochem. Int. 13, 85-88.

Moncaster S. J., Bottrell S. H., Tellam J. H., Lloyd J. W. and Konhauser K. O. (2000) Migration and attenuation of agrochemical pollutants: insights from isotopic analysis of groundwater sulphate. J. Contam. Hydrol. 43, 147-163.

Mudge D. C. (1978) Stratigraphy and sedimentation of the Lower Inferior Oolite of the Cotswolds. J. Geol. Soc. 135, 611-627.

Müldner G. and Richards M. P. (2005) Fast or feast: reconstructing diet in later medieval England by stable isotope analysis. $J$. Archaeol. Sci. 32, 39-48.

Müldner G. and Richards M. P. (2007) Stable isotope evidence for 1,500 years of human diet at the city of York, UK. Am. J. Phys. Anthropol. 133, 682-697.

Nehlich O. and Richards M. P. (2009) Establishing collagen quality criteria for sulphur isotope analysis of archaeological bone collagen. Archaeol. Anthropol. Sci. 1, 59-75.

Nehlich O., Boric D., Stefanovic S. and Richards M. P. (2010) Sulphur isotope evidence for freshwater fish consumption: a case study from the Danube Gorges, SE Europe. J. Archaeol. Sci. 37, 1131-1139.

Neumann R. E. (1949) The amino acid composition of gelatins, collagens and elastins from different sources. Arch. Biochem. 24, 289-298.

Nielsen H., Pilot J., Grinenko L. N., Grinenko V. A., Lein A. Y., Smith J. W. and Pankina R. G. (1991) Lithospheric sources of sulphur. In Stable Isotopes: Natural and Anthropogenic Sulphur in the Environment (eds. H. R. Krouse and V. A. Grinenko). John Wiley \& Sons, Chichester, pp. 65-132.

Noji M. and Saito K. (2003) Sulphur amino acids: biosynthesis of cysteine and methionine. In Sulphur in Plants (eds. Y. P. Abrol and A. Ahmad). Kluwer Academic Publishers, Dordrecht, pp. $135-144$.

Norton A., Booth P. and Moxham J. (2007) Extension areas 1 and 2, Tubney Wood Quarry, Tubney, Oxfordshire, Archaeological Testpitting Report, Post-excavation Assessment and Updated Project Design. Oxford Archaeological Unit Ltd., Oxford.

Paytan A., Kastner M., Campbell D. and Thiemens M. H. (1998) Sulfur isotopic composition of Cenozoic seawater sulfate. Science 282, 1459-1462.
Peterson B. J. and Fry B. (1987) Stable isotopes in ecosystem studies. Annu. Rev. Ecol. Syst. 18, 293-320.

Peterson B. J., Howarth R. W. and Garritt R. H. (1985) Multiple stable isotopes used to trace the flow of organic matter in estuarine food webs. Science 227, 1361-1363.

Privat K. L., O'Connell T. C. and Hedges R. E. M. (2007) The distinction between freshwater- and terrestrial-based diets: methodological concerns and archaeological applications of sulphur stable isotope analysis. J. Archaeol. Sci. 34, 1197-1204.

Prowse T. L., Schwarcz H. P., Saunders S., Macchiarelli R. and Bondioli L. (2004) Isotopic paleodiet studies of skeletons from the Imperial Roman-age cemetery of Isola Sacra, Rome, Italy. J. Archaeol. Sci. 31, 259-272.

Rees C. E., Jenkins W. J. and Monster J. (1978) The sulphur isotopic composition of ocean water sulphate. Geochim. Cosmochim. Acta 42, 377-381.

Richards M. P. and Hedges R. E. M. (1999) Stable isotope evidence for similarities in the types of marine foods used by Late Mesolithic humans at sites along the Atlantic Coast of Europe. J. Archaeol. Sci. 26, 717-722.

Richards M. P., Fuller B. T. and Hedges R. E. M. (2001) Sulphur isotopic variation in ancient bone collagen from Europe: implications for human palaeodiet, residence mobility, and modern pollutant studies. Earth Planet. Sci. Lett. 191, 185-190.

Richards M. P., Fuller B. T., Sponheimer M., Robinson T. and Ayliffe L. (2003) Sulphur isotopes in palaeodietary studies: a review and results from a controlled feeding experiment. Int. $J$. Osteoarchaeol. 13, 37-45.

Rutgers L. V., van Strydonck M., Boudin M. and van der Linde C. (2009) Stable isotope data from the early Christian catacombs of ancient Rome: new insights into the dietary habits of Rome's early Christians. J. Archaeol. Sci. 36, 1127-1134.

Scherer H. W. (2009) Sulfur in soils. J. Plant Nutr. Soil Sci. 172, 326-335.

Schwarcz H. P. and Burnie S. W. (1973) Influence of sedimentary environments on sulfur isotope ratios in clastic rocks: a review. Miner. Deposita 8, 264-277.

Stenhouse M. and Baxter M. (1979) The uptake of bomb ${ }^{14} \mathrm{C}$ in humans. In Radiocarbon Dating (eds. R. Berger and H. E. Suess). University of California Press, Berkeley, pp. 324-341.

Tanz N. and Schmidt H. (2010) $\delta^{34}$ S-Value measurements in food origin assignments and sulfur isotope fractionations in plants and animals. J. Agric. Food Chem. 58, 3139-3146.

Thode H. G. (1991) Sulphur isotopes in nature and the environment. In Stable Isotopes: Natural and Anthropogenic Sulphur in the Environment (eds. H. R. Krouse and V. A. Grinenko). John Wiley \& Sons, Chichester, pp. 1-26.

Thorp J. H., Delong M. D., Greenwood K. S. and Casper A. F. (1998) Isotopic analysis of three food web theories in constricted and floodplain regions of a Large River. Oecologia 117, 551-563.

Trust B. A. and Fry B. (1992) Stable sulphur isotopes in plants: a review. Plant, Cell Environ. 15, 1105-1110.

van Klinken G. (1999) Bone collagen quality indicators for palaeodietary and radiocarbon measurement. J. Archaeol. Sci. 26, 687-695.

Vika E. (2009) Strangers in the grave? Investigating local provenance in a Greek Bronze Age mass burial using $\delta^{34} \mathrm{~S}$ analysis. $J$. Archaeol. Sci. 36, 2024-2028.

Watts A. B., McKerrow W. S. and Fielding E. (2000) Lithospheric flexure, uplift, and landscape evolution in South-Central England. J. Geol. Soc. Lond. 157, 1169-1177.

Watts A. B., McKerrow W. S. and Richards K. (2005) Localized Quaternary uplift of South-Central England. J. Geol. Soc. Lond. 162, 13-24. 
Wild E., Arlamovsky K., Golser R., Kutschera W., Priller A., Puchegger S., Rom W., Steier P. and Vycudilik W. $(2000){ }^{14} \mathrm{C}$ dating with the bomb peak. Nucl. Instrum. Methods Phys. Res., Sect. B 172, 944-950.
Zhao F. and McGrath S. (1994) Extractable sulphate and organic sulphur in soils and their availability to plants. Plant Soil 164, 243-250. 